\title{
Clinical and immunochemical study of the serum IgG fraction not precipitated in a zinc-sodium salicylate reagent
}

\author{
JACQUES BADIN AND MARIE-ANNICK DENNE \\ From Unité INSERM 18, Hôpital Lariboisière, 6 rue Guy Patin, 75010 Paris, France
}

SYNOPSIS A reagent made of zinc sulphate $(0.048 \mathrm{M})$ in a $0.4 \mathrm{M}$ sodium salicylate solution at pHic $7 \cdot 3$ precipitated most of the IgG when a small volume of human serum was added. Sera with normat IgG levels or polyclonal hyperglobulinaemia showed a close correlation between total IgG and zinc-io precipitated IgG $(\mathrm{r}=+0.95)$. In clinical material, not including IgG myeloma, zinc-soluble IgG varied between 0 and $6 \mathrm{mg} / \mathrm{ml}$ and was independent of the IgG serum concentration. In 31 normaP subjects the average IgG concentration, as determined by the Technicon immunonephelometric $\vec{r}$ method, was $10.2 \pm 1.7 \mathrm{mg} / \mathrm{ml}$ for total $\mathrm{IgG}$ and $2.2 \pm 1.0 \mathrm{mg} / \mathrm{ml}$ for the soluble fraction. Among 1730 sera, including 24 from cord blood, 16 from pregnant women, and 133 from patients with miscel $\frac{\Phi}{3}$ laneous diseases, no pathological conditions except three cases of IgG myeloma were found with $a 0^{\circ}$ zinc-soluble IgG definitely above the normal values; zinc-soluble IgG levels were often low in

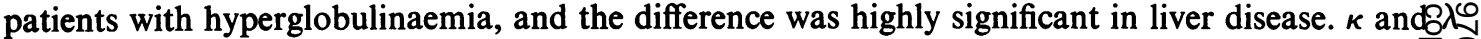
light chains as well as the four IgG-H chain subclasses were found in both zinc-soluble fractions $8 \mathrm{f}^{\circ}$ normal IgG. A study of myeloma monoclonal IgG showed that globulins of classes 1, 3, and현응 could be either soluble or insoluble in the zinc reagent. One, G2, was mainly insoluble. Hexose añds antistreptolysin contents per milligram normal IgG were not significantly different in either frac-0 tion. It is suggested that zinc-soluble IgG consists of the recently synthesized molecules, the zinc-需 solubility of which has not yet been decreased by protein association, lipid interaction, antigen bind-을 ing, or enzymatic denaturation. Within this hypothesis, a low level of soluble IgG would mean eithero an increased precatabolic protein or a decreased synthesis.

It has been reported that a reagent made up of $0.048 \mathrm{M}$ zinc sulphate in a $0.4 \mathrm{M}$ sodium salicylate solution, $\mathrm{pH} 7 \cdot 3$ and conductivity $13 \times 10^{-3}$ Mhos, selectively precipitated most of the IgG when a small volume of human serum was added (Badin and Schmitt, 1961; 1963). Albumin, $\alpha^{2} M$ globulin, and $\beta$-lipoprotein, constantly present in the precipitate, could largely be removed by dissolution of the precipitate with the minimal amount of sodium citrate and reprecipitation in the zinc reagent (Sarmini, 1973). It was also pointed out that, in most sera, a small fraction of IgG remained soluble (Badin et al, 1963), and three cases of IgG myeloma with a high level of zinc-soluble monoclonal protein have been reported (Badin et al, 1968).

Received for publication 18 February 1976
The present study was carried out in order to find? some pathological conditions other than myeloma in which the zinc-soluble IgG fraction would ben definitely above or below its normal values. Such anomalies could eventually indicate an abnorma 5 immunological status and have some diagnostic or prognostic value. The biological meaning of zinc $\frac{7}{O}$ soluble IgG was also explored by determining the hexose content and antistreptolysin titre, and identifying the light and heavy chain subclasses in both soluble and insoluble IgG.

Material, reagents, and procedure

Sera were obtained from 204 patients and donors. They included 31 normal sera, 16 from pregnant women, 24 from cord blood, and 133 from patients with miscellaneous diseases with and without hyper-984 


\begin{tabular}{|c|c|c|c|c|c|}
\hline \multirow[t]{2}{*}{ Group } & \multirow[t]{2}{*}{ No. of cases } & \multicolumn{3}{|c|}{$I g G(\mathrm{mg} / \mathrm{ml}$ serum $)$} & \multirow{2}{*}{$\begin{array}{l}\text { IgG not precipitated } \\
\text { in zinc reagent: } \\
\text { signvicance of } \\
\text { differences from } \\
\text { normal values }\end{array}$} \\
\hline & & Total & $\begin{array}{l}\text { Zinc } \\
\text { precipitate } \\
\text { (insoluble } I g G)\end{array}$ & $\begin{array}{l}\text { Zinc } \\
\text { supernatant } \\
\text { (soluble IgG) }\end{array}$ & \\
\hline $\begin{array}{l}\text { Blood donors } \\
\text { Pregnancy } \\
\text { Cord blood } \\
\text { Untreated miscellaneous cancers } \\
\text { Cancer under chemotherapy } \\
\text { Rheumatoid arthritis } \\
\text { Lupus ED and diffuse collagenoses } \\
\text { Miscellaneous chronic rheumatism } \\
\text { Streptococcal infection } \\
\text { Paget's disease, osteoporosis, and malacia } \\
\text { Active syphilis } \\
\text { Liver cirrhosis and hepatitis } \\
\text { Cardiovascular diseases }\end{array}$ & $\begin{array}{r}31 \\
16 \\
24 \\
21 \\
16 \\
19 \\
14 \\
7 \\
6 \\
12 \\
19 \\
13 \\
6\end{array}$ & $\begin{array}{l}10.7 \pm 1 \cdot 7 \\
11.6 \pm 2.6 \\
12 \cdot 1 \pm 2 \cdot 4 \\
12 \cdot 2 \pm 3 \cdot 4 \\
11.0 \pm 3 \cdot 8 \\
12 \cdot 1 \pm 3.4 \\
16.4 \pm 6 \cdot 3 \\
10 \cdot 4 \pm 2 \cdot 7 \\
13.4 \pm 2 \cdot 7 \\
11 \cdot 2 \pm 4.5 \\
10.8 \pm 3.6 \\
18.0 \pm 5 \cdot 1 \\
10.6 \pm 2.2\end{array}$ & $\begin{array}{r}8 \cdot 5 \pm 1 \cdot 7 \\
9 \cdot 6 \pm 2 \cdot 5 \\
10 \cdot 3 \pm 2 \cdot 7 \\
10.3 \pm 3 \cdot 8 \\
9 \cdot 1 \pm 3 \cdot 2 \\
10 \cdot 2 \pm 3 \cdot 1 \\
14.5 \pm 6 \cdot 0 \\
8.9 \pm 2 \cdot 6 \\
11 \cdot 4 \pm 2 \cdot 8 \\
9 \cdot 5 \pm 4 \cdot 1 \\
9 \cdot 2 \pm 3 \cdot 2 \\
16.7 \pm 5 \cdot 7 \\
9 \cdot 2 \pm 1 \cdot 8\end{array}$ & $\begin{array}{l}2.2 \pm 1.0 \\
2.0 \pm 0.7 \\
1.8 \pm 0.8 \\
1.8 \pm 0.8 \\
1.9 \pm 0.9 \\
1.9 \pm 1.0 \\
1.9 \pm 1.7 \\
1.5 \pm 0.9 \\
2.0 \pm 1.4 \\
1.7 \pm 1.0 \\
1.6 \pm 1.0 \\
1.3 \pm 1.4 \\
1.4 \pm 0.7\end{array}$ & $\begin{array}{l}\text { NS } \\
\text { NS } \\
\text { NS } \\
\text { NS } \\
\text { NS } \\
\text { NS } \\
\text { NS } \\
\text { NS } \\
\text { NS } \\
\text { NS } \\
\text { S(P } \leqslant 0 \cdot 01) \\
\text { Insufficient number }\end{array}$ \\
\hline
\end{tabular}

Table I Zinc-precipitated and zinc-soluble IgG in normal subjects and in various clinical conditions

globulinaemia. These diseases are listed in table I.

(1) The zinc reagent was prepared according to Badin and Schmitt (1961).

In $700 \mathrm{ml}$ of previously boiled distilled water, $40 \mathrm{~g}$ pure sodium salicylate was dissolved; in a small beaker, $1.3 \mathrm{~g}$ zinc sulphate $6 \mathrm{H}_{2} \mathrm{O}$ was dissolved in $20 \mathrm{ml}$ distilled water. Both solutions were mixed and the $\mathrm{pH}$ was brought up to $7 \cdot 3$ by the slow addition of $0.1 \mathrm{~N}$ uncarbonated $\mathrm{NaOH}$. To avoid the formation of zinc hydroxide, drops must fall on a glass rod before reaching the reagent which is stirred magnetically. After bringing the volume up to $1000 \mathrm{ml}$, the clear fluid can be kept for several years in a dark glass.

(2) Immunological determination of IgG in sera and in zinc precipitate solutions was done automatically by immunonephelometry at $350 \mathrm{~nm}$ with a Technicon AutoAnalyzer (Larson et al, 1972; Ritchie, 1974). Direct IgG determination from the supernatant was not possible because the reagent flocculated the anti-serum and absorbed the ultraviolet light. Neither could polyoxyethyleneglycol, an accelerating agent for the antigen-antibody reaction (Larson et al, 1972), be used because of an unexpected interaction with the zinc-precipitated globulin which resulted in peaks higher than those given by the corresponding volume of the tested serum.

Consequently, zinc-insoluble and -soluble JgG was determined as follows: IgG selective precipitation first performed by adding $0.05 \mathrm{ml}$ serum to $2 \mathrm{ml}$ reagent in a calibrated $7 \mathrm{ml}$ plastic tube. After whirlmixing and standing for two hours at $25^{\circ} \mathrm{C}$ in a water-bath, tubes were centrifuged at $8000 \mathrm{~g}$ for 15 minutes and the supernatant was poured off. Each tube was drained and the inner wall was dried with the tip of a filter paper. The precipitate was dissolved in $0.2 \mathrm{ml}$ sodium citrate $10 \%$ solution and the volume was brought up to $5 \mathrm{ml}$ by filling the calibrated tube with an ultrafiltered mixture of equal parts saline and $4 \%$ citrate solution. The serum was diluted in the same way by whirl-mixing $0.05 \mathrm{ml}$ serum and $4.95 \mathrm{ml}$ solution. In the Technicon manifold the glass pool was long enough to allow a 30-minute contact between the sample and the anti-IgG goat serum.

The zinc-soluble IgG concentration was calculated by deducting the value of zinc-precipitable IgG from that of the serum IgG level (fig 1).

(3) Total protein was determined by the biuret reaction (Gornall et al, 1949).

(4) Protein-bound hexose was estimated by the tryptophanborosulphuric acid method (Badin et al, 1953).

(5) Antistreptolysin was titrated by haemolysis inhibition using a highly specific method (Badin and Barillec, 1970).

(6) IgG light chains were identified by double diffusion on agar plates with specific rabbit antisera (Ouchterlony, 1962).

(7) $\mathrm{G1}, 2,3$, and 4 heavy chain subclasses (Morell et al, 1970; 1972) were kindly identified for us by Dr Skvaril (Institut für klinische Tumorforschung, Bern, Switzerland).

Myeloma sera and myeloma monoclonal IgG with known subclasses were kindly given to us by Dr Fine (Centre National de la Transfusion Sanguine) and Dr Seligmann (Hôpital Saint Louis, Paris). These immunoglobulins had been purified by ammonium sulphate followed by precipitation of contaminating proteins by caprylic acid (Fine and Steinbuch, 1970). IgG was dissolved in either saline or normal serum before being tested.

(8) Statistical data were assessed with a Wang computer. 


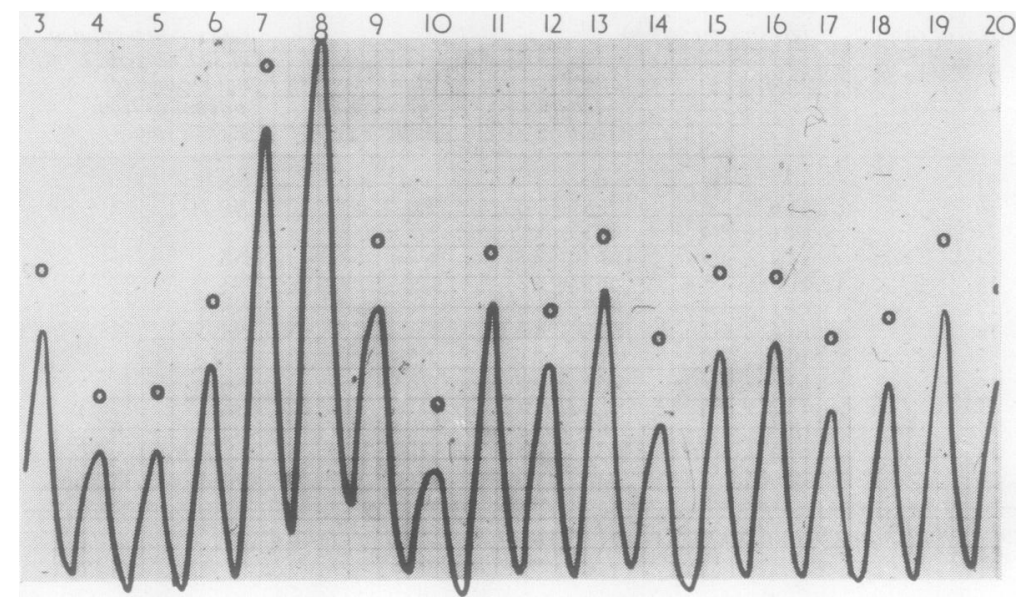

Fig 1 Automated determination of zinc-soluble and zinc-insoluble IgG by the Technicon immunonephelometric method. Each peak corresponds to the determination of zinc-precipitated IgG in a serum. The circles above the peaks indicate the top of the peaks which would correspond to the determination of total IgG in the same sera. Zinc-soluble IgG levels are given by the difference between the top of the peaks and the circles. This figure clearly shows the independence of zinc-soluble IgG, the amount of which does not depend on serum total IgG level.

\section{Results}

The precision of the nephelometric immunodetermination of IgG was assessed by 15 successive assays of the same pooled serum. The coefficients of variation were $3.8 \%$ for serum and $7.5 \%$ for zinc precipitate.

QUANTITATION OF ZINC-PRECIPITATED

AND ZINC-SOLUBLE IGG IN VARIOUS

NORMAL AND PATHOLOGICAL CONDITIONS

As shown in table $I$ and fig 2, the variations of precipitated IgG closely followed the serum IgG levels $(r=+0.95)$. Soluble IgG generally showed little change and, surprisingly, the variations appeared to be quite independent not only of the levels of total IgG but also of the level of other proteins with zinc-binding capacity. In particular, the addition to sera of crystallized albumin up to 20 $\mathrm{mg} / \mathrm{ml}$ did not influence the IgG precipitation. In normal serum, average values were $8.5 \pm 1.7 \mathrm{mg} / \mathrm{ml}$ for zinc-precipitated IgG and $2 \cdot 2 \pm 0.1 \mathrm{mg} / \mathrm{ml}$ for soluble IgG. Levels of soluble IgG above $3 \mathrm{mg} / \mathrm{ml}$ were relatively frequent in normal sera ( 7 out of 31 ). The highest figure was $4.10 \mathrm{mg} / \mathrm{ml}$. No case was found with a concentration below $1 \mathrm{mg} / \mathrm{ml}$. Among the pathological sera there were no cases with a zinc-soluble IgG level significantly higher than normal except the three cases of IgG myeloma men- tioned above. Although there was no particutar disease with a constantly low level of zinc-solutie IgG, low levels were more common in sera with higt gamma globulin levels (tables II and III). For exg ample, among sera with IgG levels below $10 \mathrm{mg} / \mathrm{m}$ p $8.8 \%$ were lacking zinc-soluble IgG. When IgG was.

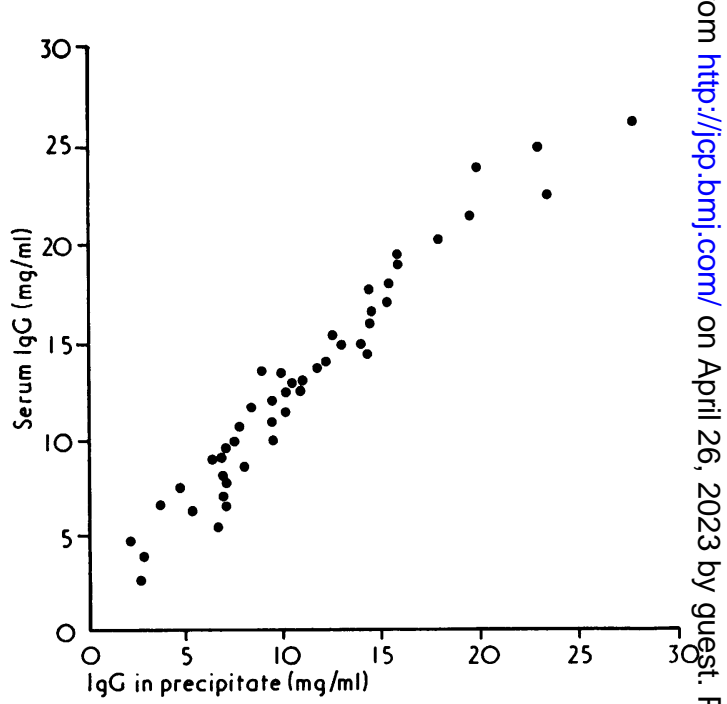

Fig 2 Correlation between serum total IgG and zinc-precipitated IgG $(r=+0.95)$, myelomas not included 


\begin{tabular}{|c|c|c|c|}
\hline \multicolumn{2}{|l|}{ Total serum IgG } & \multicolumn{2}{|c|}{ Zinc-soluble IgG } \\
\hline Level & $m g / m l$ & $\begin{array}{l}m g / m l ~ i n \\
\text { serum }\end{array}$ & $\begin{array}{l}\% \text { Serum } \\
\text { IgG }\end{array}$ \\
\hline Low $(\leqslant 10 \mathrm{mg} / \mathrm{ml})$ & $\begin{array}{r}7.88 \\
\pm \quad 1.96\end{array}$ & $\begin{array}{r}1.27 \\
\pm 0.87\end{array}$ & $\begin{array}{r}16 \cdot 30 \\
+12 \cdot 00\end{array}$ \\
\hline $\begin{array}{l}\text { Normal and moderately } \\
\text { increased }(10 \cdot 2-15 \mathrm{mg} / \mathrm{ml})\end{array}$ & $\begin{array}{r}12.16 \\
\pm \quad 1.98\end{array}$ & $\begin{array}{r}1.96 \\
\pm 1.03\end{array}$ & $\begin{array}{r}16 \cdot 20 \\
\pm \quad 8 \cdot 20\end{array}$ \\
\hline High $(>15 \mathrm{mg} / \mathrm{ml})$ & $\begin{array}{r}19.90 \\
+\quad 3.60\end{array}$ & $\begin{array}{r}1.72 \\
\pm 1.65\end{array}$ & $\begin{array}{r}9 \cdot 28 \\
\pm \quad 8 \cdot 50\end{array}$ \\
\hline
\end{tabular}

Table II Relationship of zinc-soluble IgG to serum IgG level (mean values $\pm S D$ )

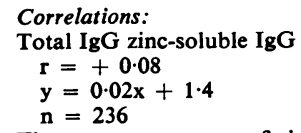

Total IgG zinc-precipitated IgG $\mathbf{r}=+0.95$$$
y=x-1.60
$$$$
\mathrm{n}=236
$$

The mean percentage of zinc-soluble IgG is low when serum IgG is increased because of the frequent lack of soluble $\mathrm{IgG}$ in sera with high levels of IgG. There is no significant correlation between total IgG and zinc-soluble IgG.

\begin{tabular}{|c|c|c|}
\hline \multirow[t]{2}{*}{ Tested cases (no.) } & \multicolumn{2}{|c|}{$\begin{array}{l}\text { Zinc-soluble IgG per } \mathrm{ml} \text { in } \\
\text { serum ( } \% \text { of cases) }\end{array}$} \\
\hline & $>3 \mathrm{mg}$ & $<0.5 \mathrm{mg}$ \\
\hline Blood donors (31) & 19 & 0 \\
\hline Pregnancy (16) & 12 & 6 \\
\hline Cord blood (12) & 0 & 16 \\
\hline Miscellaneous cancers (27) & 11 & 16 \\
\hline Rheumatoid arthritis & 10 & 15 \\
\hline LED and diffuse collagenoses (14) & 21 & 35 \\
\hline \multicolumn{3}{|l|}{ Chronic rheumatoid other than } \\
\hline rheumatoid arthritis (7) & 14 & 14 \\
\hline Streptococcal infection (6) & 16 & 16 \\
\hline \multicolumn{3}{|l|}{ Bone and calcium metabolism } \\
\hline disturbance (12) & 8 & 8 \\
\hline Active syphilis (19) & 10 & 15 \\
\hline Liver disease (13) & 7 & 46 \\
\hline
\end{tabular}

Table III Highest and lowest amounts of zinc-soluble IgG in miscellaneous clinical conditions

\begin{tabular}{llll}
\hline IgG myeloma & Serum IgG & $\begin{array}{l}\text { Zinc- } \\
\text { precipitated IgG }\end{array}$ & $\begin{array}{l}\text { Zinc-soluble } \\
\text { IgG }\end{array}$ \\
\hline 1 & $17 \cdot 4$ & $12 \cdot 2$ & $5 \cdot 2$ \\
2 & $14 \cdot 7$ & $14 \cdot 0$ & $0 \cdot 7$ \\
3 & $12 \cdot 7$ & $10 \cdot 8$ & $1 \cdot 9$ \\
4 & $26 \cdot 5$ & $25 \cdot 6$ & 0 \\
5 & $6 \cdot 1$ & $5 \cdot 5$ & $0 \cdot 6$ \\
6 & $20 \cdot 3$ & $18 \cdot 1$ & $2 \cdot 2$ \\
7 & $21 \cdot 0$ & $21 \cdot 0$ & 0 \\
8 & 30 & $5 \cdot 0$ & $18^{1}$ \\
9 & 56 & 0 & $56^{1}$ \\
10 & 22 & 10 & $12^{1}$ \\
\hline
\end{tabular}

Table IV Zinc-precipitation of myeloma IgG

${ }^{1}$ Cases taken from a previous study.

between $10 \cdot 1$ and $15 \mathrm{mg} / \mathrm{ml}, 7 \cdot 8 \%$ cases were lacking soluble IgG, and when the IgG serum level was above $15 \mathrm{mg} / \mathrm{ml} 38.5 \%$ cases were lacking soluble IgG. $2^{*}$ hyperglobulinaemia since significantly low levels were occasionally found in some sera with normal IgG levels. Zinc-soluble IgG levels were significantly lower than normal only in liver disease.

In the 10 myeloma sera included in this study (table IV), zinc-soluble IgG was absent in three cases, low in two, normal in two, slightly increased in one, and very much increased in three. In one of these, IgG at a serum concentration of $56 \mathrm{mg} / \mathrm{ml}$ was totally soluble in the zinc reagent.

\section{IDENTIFICATION OF LIGHT AND HEAVY CHAIN SUBCLASSES IN ZINC-SOLUBLE AND -INSOLUBLE IgG (Schur, 1972)}

Testing of subclasses in the zinc-soluble and-insoluble fractions of normal pooled IgG

Immunoelectrophoresis of both fractions against specific $\mathrm{H}$ chain antisera (Dr Skvaril) showed that the four subclasses were present in both fractions. $\kappa$ and $\lambda$ light chains were also characterized in both fractions.

Study of purified myeloma $\operatorname{IgG}$ with known subclasses The 10 available preparations were tested for zinc precipitation after dissolution in either saline or normal serum. Table $\mathrm{V}$ shows that, in most of the cases, the protein was not totally soluble or insoluble in the zinc reagent.

This fact may be related mainly to the presence of small amounts of normal IgG from the other subclasses beside the dominant monoclonal myeloma globulin. Contaminating proteins may also have increased the quantity of zinc-soluble protein in the preparation. On the other hand, part of the soluble monoclonal globulins may have been denatured during the purification process and consequently lost their solubility in the zinc reagent. If we consider that pure, undenatured monoclonal IgG would be totally soluble or insoluble in the zinc reagent, our results show that IgG solubility in the zinc reagent is not related to subclass:

Out of five G1, four were insoluble and one soluble.

One $\mathrm{G} 2$ was found to be mainly precipitated.

Out of three G4, one was insoluble and two soluble.

Of two G3, one was soluble and the other insoluble.

No relation was found between zinc solubility and electrophoretic mobility. The best evidence was given by one fast moving G4 which was insoluble and one G1 with a very low mobility which was soluble. The properties of these immunoglobulins were indeed opposite to those of the other investigated globulins: the other G4s were rather 'fast 


\begin{tabular}{|c|c|c|c|c|}
\hline \multirow{2}{*}{ Isolated subclassified monoclonal IgG } & \multicolumn{2}{|c|}{ IgG dissolved in saline } & \multicolumn{2}{|c|}{ IgG dissolved in normal serum } \\
\hline & $\begin{array}{l}\text { Zinc-precipitated } \\
(\% \text { total IgG) }\end{array}$ & $\begin{array}{l}\text { Zinc-soluble } \\
(\% \text { total IgG) }\end{array}$ & $\begin{array}{l}\text { Zinc-precipitated } \\
(\% \text { total IgG) }\end{array}$ & $\begin{array}{l}\text { Zinc-soluble } \\
(\% \text { total IgG) }\end{array}$ \\
\hline $\begin{array}{l}\text { G1 (Dr Fine) } \\
\text { G1 (Dr Fine) } \\
\text { G1 (Dr Seligmann) } \\
\text { G1 (Dr Seligmann) } \\
\text { G1 (Stum ....) } \\
\text { G2 (Dr Fine) } \\
\text { G3 (Dr Seligmann) } \\
\text { G3 (Mett ...) } \\
\text { G4 (Dr Seligmann) } \\
\text { G4 (Dr Fine) }\end{array}$ & $\begin{array}{r}80 \\
85 \\
100 \\
85 \\
10 \\
84 \\
0 \\
86 \\
70 \\
32\end{array}$ & $\begin{array}{r}20 \\
15 \\
0 \\
15 \\
90 \\
16 \\
100 \\
14 \\
30 \\
68\end{array}$ & $\begin{array}{l}80 \\
89 \\
\text { Insufficient quantity } \\
\text { Insufficient quantity } \\
0 \\
53 \\
0 \\
86 \\
60 \\
17\end{array}$ & $\begin{array}{r}100 \\
47 \\
100 \\
14 \\
40 \\
73\end{array}$ \\
\hline
\end{tabular}

Table V Solubility of some myeloma globulins of different subclasses in the zinc-reagent

It seems probable that in all cases the monoclonal myeloma globulin was either totally soluble or insoluble in the zinc reagent and that the smalle IgG fraction consisted of either denatured myeloma globules or IgG of the other subclasses eventually present in the IgG preparation.

\begin{tabular}{|c|c|c|c|c|c|}
\hline & & Protein $(\mu g)$ & Hexose $(\mu g)$ & $\%$ Hexose in protein & $\stackrel{\infty}{\infty}$ \\
\hline 1 & $\begin{array}{l}\text { Precipitate } \\
\text { Supernatant }\end{array}$ & $\begin{array}{l}2700 \\
1900\end{array}$ & $\begin{array}{l}27 \\
26\end{array}$ & $\begin{array}{l}1 \\
\ldots \ldots \ldots \ldots \ldots 1 \cdot 37\end{array}$ & 윽 \\
\hline 2 & $\begin{array}{l}\text { Precipitate } \\
\text { Supernatant }\end{array}$ & $\begin{array}{l}2500 \\
2300\end{array}$ & $\begin{array}{l}24 \\
28\end{array}$ & $\begin{array}{l}0.96 \\
\ldots \ldots \ldots \ldots \ldots \ldots 1 \cdot 21\end{array}$ & $\vec{Z}$ \\
\hline 3 & $\begin{array}{l}\text { Precipitate } \\
\text { Supernatant }\end{array}$ & $\begin{array}{l}3000 \\
4600\end{array}$ & $\begin{array}{l}29 \\
51\end{array}$ & $\begin{array}{l}0.95 \\
\ldots \ldots \ldots \ldots \ldots 1 \cdot 19\end{array}$ & $\frac{0}{\Phi}$ \\
\hline 4 & $\begin{array}{l}\text { Precipitate } \\
\text { Supernatant }\end{array}$ & $\begin{array}{l}1600 \\
2800\end{array}$ & $\begin{array}{l}17 \\
29\end{array}$ & $\begin{array}{l}1.06 \\
\ldots \ldots \ldots \ldots \ldots 1.03\end{array}$ & 윰 \\
\hline 5 & $\begin{array}{l}\text { Precipitate } \\
\text { Supernatant }\end{array}$ & $\begin{array}{l}1400 \\
3100\end{array}$ & $\begin{array}{l}16 \\
28\end{array}$ & $\begin{array}{l}1 \cdot 14 \\
\ldots \ldots \ldots \ldots \ldots \ldots 0 \cdot 90\end{array}$ & ○ $\vec{\vartheta}$ \\
\hline & $\begin{array}{l}\text { Precipitate } \\
\text { Supernatant }\end{array}$ & & & $\begin{array}{l}1 \cdot 02 \\
\ldots \ldots \ldots \ldots \ldots 1 \cdot 13\end{array}$ & 冚 \\
\hline
\end{tabular}

migrating' and zinc-soluble; the other G1s were slow moving and zinc-precipitated. It must also be pointed out that there was no relationship between light chains and zinc solubility.

\section{ATTEMPT TO ASCERTAIN QUALITATIVE \\ DIFFERENCES BETWEEN FRACTIONS OF \\ NORMAL IgG INSOLUBLE AND SOLUBLE IN \\ THE ZINC REAGENT}

As indicated in table VI, the hexose content was not significantly different in either fraction.

The antistreptolysin titre per milligram protein (table VII) was somewhat lower for zinc-soluble IgG, but it is doubtful whether this difference was significant, and both fractions appear to have a good capacity to become antistreptolysin.

\section{Discussion}

A zinc-glycinate-acetate solution was the first zinc reagent described for estimation of serum gamma globulin (Surgenor et al, 1960). We found that this reagent precipitated more than a third of the plasma protein but the quantity was poorly correlated with $\overrightarrow{\overrightarrow{0}}$ the IgG level. In contrast, the precipitate obtained with the zinc sodium-salicylate reagent was well cor related with the $\operatorname{IgG}$ serum level $(\mathrm{r}=+0.77)$ alo though the immunoglobulin represented only $49 \%$ of the precipitated protein from normal sera. The contaminating proteins appeared to be absorbed mainly on the precipitated IgG since they were in great part removed by two successive precipitations. As expected, no precipitate occurred when sera wereo deprived of IgG (agammaglobulinaemia) (Badin and Schmitt, 1963). In the optimal conditions here deo scribed for selective zinc precipitation of IgG, the correlation between serum IgG and zinc-precipitatedos IgG was very high $(r=+0.95)$ although the metal cation did not precipitate all of this immuno+ globulin. It is shown here that about $20 \%$ of the IgG in normal serum $(2.2 \mathrm{mg} / \mathrm{ml})$ remains soluble in the reagent at $25^{\circ} \mathrm{C}$. In the common diseases of Europe which were investigated, zinc-soluble IgG remained in the narrow range of 0 to $6 \mathrm{mg} / \mathrm{ml}$ while zinc-precipitated IgG varied between 0 and $56 \mathrm{mg} / 100$ Unexpectedly, the quantitative variation of this 


\begin{tabular}{|c|c|c|c|}
\hline & $A S L(I U)$ & Protein (mg) & $A S L(I U)$ per mg IgG \\
\hline $\begin{array}{l}\text { Serum } 1 \\
\quad \text { Zinc precipitate } \\
\text { Supernatant }^{1}\end{array}$ & $\begin{array}{l}480 \\
320 \\
128\end{array}$ & $\begin{array}{l}13 \cdot 5 \\
9 \\
4 \cdot 5\end{array}$ & $\begin{array}{l}35 \cdot 6 \\
\ldots \ldots \ldots \ldots 35 \cdot 6 \\
\ldots \ldots \ldots \ldots \ldots \ldots \ldots 28 \cdot 3\end{array}$ \\
\hline $\begin{array}{l}\text { Serum } 2 \\
\quad \text { Zinc precipitate } \\
\text { Supernatant }^{1}\end{array}$ & $\begin{array}{r}800 \\
640 \\
96\end{array}$ & $\begin{array}{r}14 \cdot 3 \\
12 \cdot 3 \\
2 \cdot 0\end{array}$ & $\begin{array}{l}56 \\
\ldots \ldots \ldots \ldots 52 \\
\ldots \ldots \ldots \ldots \ldots \ldots \ldots, 48\end{array}$ \\
\hline $\begin{array}{l}\text { Serum } 3 \\
\quad \text { Supernatant }{ }^{1}\end{array}$ & $\begin{array}{r}100 \\
16\end{array}$ & $\begin{array}{r}14 \cdot 1 \\
2 \cdot 8\end{array}$ & $\begin{array}{l}7 \cdot 1 \\
\ldots \ldots \ldots \ldots \ldots \ldots \ldots 5 \cdot 7\end{array}$ \\
\hline $\begin{array}{l}\text { Serum } 4 \\
\quad \text { Supernatant }{ }^{1}\end{array}$ & $\begin{array}{r}160 \\
16\end{array}$ & $\begin{array}{l}9 \cdot 1 \\
0 \cdot 9\end{array}$ & $\begin{array}{l}17 \cdot 6 \\
\ldots \ldots \ldots \ldots \ldots \ldots \ldots 17 \cdot 8\end{array}$ \\
\hline $\begin{array}{l}\text { Gammaglobulin F II } \\
\text { Supernatant }{ }^{1}\end{array}$ & $\begin{array}{r}480 \\
10\end{array}$ & $\begin{array}{l}59 \\
1.7\end{array}$ & $\begin{array}{l}8 \cdot 1 \\
\ldots \ldots \ldots \ldots \ldots \ldots \ldots .9 .9\end{array}$ \\
\hline $\begin{array}{l}\text { Serum IgG or } \gamma \text { globul } \\
\text { Zinc-soluble IgG }\end{array}$ & & & $\begin{array}{l}37 \cdot 6 \\
\ldots \ldots\end{array}$ \\
\hline
\end{tabular}

Table VII Antistreptolysin (ASL) in zinc-insoluble and zinc-soluble IgG

'Zinc reagent and serum after removal of insoluble proteins by centrifugation.

Supernatants were dialysed $18 \mathrm{~h}$ against saline and a few hours against a concentrated polyvinyl pyrrolidone solution to reduce the fluid volume to $10-20 \%$ of the initial volume.

fraction appeared to be independent from that of the serum total IgG level.

With the exception of three cases of IgG myeloma, no condition was found with zinc-soluble IgG levels definitely higher than normal, and low values or an absence of this fraction have been found frequently only in patients with hyperglobulinaemia and more significantly in cases of liver disease.

Zinc has been used for three decades by several investigators to precipitate selectively immunoglobulins with a different purpose such as gamma globulin isolation (Gurd and Wilcox, 1956; Surgenor et al, 1960), clinical estimation of the serum gamma globulin concentration (Kunkel, 1947; Schmid, 1950), and antibody fractionation (Isliker and Antoniades, 1955). However, the presence of an IgG fraction which did not precipitate with zinc was not mentioned until 1963. At this time our chromotographic study of zinc-insoluble and -soluble plasmaproteins (Badin et al, 1963), followed by the report of three cases of myeloma with high levels of zincsoluble IgG (Badin et al, 1968), ascertained the individuality of this fraction.

The biological meaning of zinc-soluble IgG remains unknown. Hexose content and antistreptolysin titres were not found to be much different from those of IgG which precipitated with zinc. $\kappa$ and $\lambda$ light chains and the four H-chain subclasses were found in both fractions of IgG isolated from normal sera.

Monoclonal globulins in myeloma sera or isolated from myeloma sera belonging to each of the subclasess were found to be either soluble or insoluble in the zinc reagent. Finally, no relation was found between solubility and electrophoretic migra- tion. The solubility of monoclonal IgG in the zinc reagent should allegedly depend on an increased availability of histidyl residues; it is indeed known that zinc ++ binds to proteins probably exclusively through histidine (Gurd and Goodman, 1952; Gurd and Wilcox, 1956; Sarmini, 1973).

Although not yet characterized by some immunological or physicochemical feature, the zinc-soluble part of polyclonal IgG may have a biological meaning of its own.

We have noticed that purified IgG was more rapidly and completely precipitated after a slight denaturation induced by salting out or a brief heating at $63^{\circ} \mathrm{C}$. It can be speculated that soluble IgG might consist of the most recently synthesized molecules which have not yet been denatured by enzymatic degradation in blood, lipid binding or immunological interaction and have therefore kept free the majority of their hydrophilic groups. Thus the low values of zinc-soluble IgG found in some patients may express a slow synthesis or an exaggerated precatabolic alteration of $\mathbf{I g G}$.

We are grateful to Professor F. Skvaril, Director of the Institut für Tumorforschung, Bern, Switzerland, who kindly studied our preparations and helped us to identify the IgG subclasses; and to Mr Jean Gaumeton, Director of the biochemical department of Technicon, France, who gave us the technical and financial support which made this work possible. The excellent technical assistance of Mrs F. Maillet was much appreciated. We thank Professor M. Seligmann and Dr J. M. Fine for kindly supplying us with samples of rare sera. We acknowledge some financial support from the INSERM. 


\section{References}

Badin, J. and Barillec, A. (1970). Streptolysin O inhibition by serum gamma-G globulin and $\beta$-lipoprotein after blocking of nonesterified cholesterol by digitonin. J. Lab. clin. Med., 75, 975-982.

Badin, J., Jackson, C., and Schubert, M. (1953). Improved method for determination of plasma polysaccharides with tryptophan. Proc. Soc. exp. Biol. (N.Y.), 84, 288-291.

Badin, J., Rousselet, F., and Hervé, B. (1963). Étude qualitative des globulines gamma par une méthode associant la précipitation zincique en milieu salicylé, le relargage par le sulfate de soude et la chromatographie sur cellulose DEAE. Ann. Biol. clin., 21, 219-240.

Badin, J. and Schmitt, F. (1961). Précipitation des gammaglobulines dans un réactif associant le zinc et le salicylate de soude. Nature des précipités. Effets des inhibiteurs de la floculation en fonction de la force ionique. Bull Soc. Chim. biol. (Paris), 43, 387-408.

Badin, J. and Schmitt, F. (1963). Méthode de dosage des gamma-globulınes par précipitation zincique en milieu de force ionique élevée: comparaison avec l'électrophorèse, la précipitation en solution zincique diluée et le relargage au sulfate d'ammonium. Path. et Biol., 11, 195-201.

Badin, J., Trensz, F., and Rousselet, F. (1968). Individualité d'une fraction de $\gamma$-G globulines non précipitables par le zinc à pH 7·3. Clin. chim. Acta, 19, 11-18.

Fine, J. M. and Steinbuch, M. (1970). Etudes sur les IgG monoclonales. I. Méthode d'isolement basée sur la solubilité de ces protéines et étude. Par l'électrophorèse en gel d'amidon-urée, des produits de réduction-alkylation de ces immunoglobulines. Rev. franc. Transfus., 13, 153-164.

Gornall, A. G., Bardawill, C. J., and David, M. M. (1949). Determination of serum proteins by means of the biuret reaction. J. biol. Chem., 177, 751-755.

Gurd, F. R. N. and Goodman, D. S. (1952). Preparation and properties of serum and plasma proteins. XXXII. The interaction of human serum albumin with zinc ions. $J$.
Amer. chem. Soc., 74, 670-675.

Gurd, F. R. and Wilcox, P. E. (1956). Complex formation between metallic cations and proteins, peptides and amino음 acids. Advanc. Protein Chem., 11, 311-427.

Isliker, H. C. and Antoniades, H. N. (1955). Fractionation of antibodies from human $\gamma$-globulins with zinc salts. $J_{0}$ Amer. chem. Soc., 77, 5863-5867.

Kunkel, H. G. (1947). Estimation of alterations of serum gamma globulin by a turbidimetric technique. Proc. Soc. exp. Biol. (N.Y.), 66, 217-226.

Larson, C. C., Gorman, J. M., and Becker, A. (1972) Automated immuno-precipitin system for proteins in bodycs fluids. In Advances in Automated Analysis: Technicon International Congress, Vol. 4.

Morell, A., Skvaril, F., Steinberg, A. G., Van Loghem, E., $\vec{\omega}$ and Terry, W. D. (1972). Correlations between the concentrations of the four subclasses of $\mathrm{IgG}$ and $\mathrm{Gm}$ cellotypes in normal human sera. J. Immunol., 108, 195-206.

Morell, A., Terry, W. D., and Waldmann, T. A. (1970). N Metabolic properties of IgG subclasses in man. J. clin. Invest., 49, 673-680.

Ouchterlony, O. (1962). Diffusion-in-gel methods for im-i munological analysis II. Prog. Allergy, 6, 30-154.

Ritchie, R. F. (1974). Theory and practice of automated nephelometry. Protides biol. fluids, 21, 569-578.

Sarmini, H. (1973). Sur Quelques Aspects de la Biochimie duZinc: Liaisons Protéines-Zinc et Intérêt Clinique. Thesis, $Z$

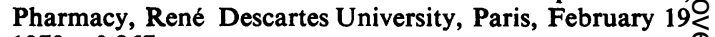
$1973, n^{\circ} 267$.

Schmid, R. (1950). The zinc turbidity test and its clinical application. J. Lab. clin. Med., 36, 52-65.

Schur, P. H. (1972). Human gamma-G subclasses. Progr. clin. Immunol., 1, 71-104.

Surgenor, D. M., Pennell, R. B., Alameri, E., Batchelor, W. H., Brown, R. K., Hunter, M. J., and Mannick, V. (1960). Preparation and properties of serum and plasriaproteins. XXXV. A system of protein fractionation using zinc complexes. Vox Sang. (Basel), 5, 272-269. 